\title{
The production of 18 th century scientific knowledge about the Brazilian Caatinga
}

\section{A produção do conhecimento científico sobre a Caatinga brasileira no século $\mathrm{XVIII}$ \\ DOI: 10.5935/2237-2717.20160009}

\author{
Magnus Roberto de Mello Pereira \\ Universidade Federal do Paraná \\ magnusdocs@gmail.com \\ Curitiba \\ Brasil \\ Cláudio DeNipoti \\ Universidade Estadual de Ponta Grossa \\ cldenipoti@gmail.com \\ Ponta Grossa \\ Brasil
}

Recibido: 21 de marzo de 2016

Aprobado: 17 de mayo de 2016

\begin{abstract}
How science has defined a "region" over time, is the main question brought forth by this article. As part of a scientific effort, orchestrated by a central, despotic Imperial Government, co opting colonial subjects into becoming scientists at the service of the Crown, who described, named and defined the various parts of the empire. Thus, the Caatinga of Northeastern Brazil has been the subject of several descriptions during the 18th Century, written by naturalists in the service of the Portuguese Crown. - These men sent, over the last decades of the 18th through early 19th Century, a large number of samples of minerals, fauna and flora to be studied and described in Lisbon and other European capitals, creating the necessary environment for a scientific boom which never really took place but for the few printed and manuscript reports which were the sources for this article.
\end{abstract}

\section{KEYWORDS}

18th Century, Science; Philosophic Voyages, Portuguese Empire, Brazilian Caatinga.

\section{RESUMO}

Como a ciência definiu uma "região" ao longo do tempo é a principal questão levantada por este artigo. Como parte de um esforço científico, orquestrado por um governo imperial central e despótico, cooptando súditos coloniais em se tornarem cientistas ao serviço da coroa, que descreveram, nomearam e definiram as várias partes do império. Assim, a Caatinga do nordeste brasileiro foi objeto de diversas descrições durante o século XVIII, escritas por naturalistas a serviço da coroa portuguesa. Estes homens, durante as últimas décadas do século XVIII e as primeiras do XIX, enviaram amostras minerais, vegetais e animais para serem estudadas e descritas em Lisboa e outras capitais europeias, criando 0 ambiente necessário para uma expansão científica que nunca realmente aconteceu, exceto por alguns relatos impressos e manustritos, que foram as fontes desta investigação.

\section{PalaVRas-chaves}

Século XVIII, Ciência, Viagens Filosóficas, Império Português, Caatinga.

The many ways in which any specific "region" is described, analyzed, and studied has been both a question and a focus of the historiography Science and Scientific thought, and the studies of identities of the early 21st Century. This work aims to see how a "region" - both geographically and culturally defined - came into existence in the 18th Century Portuguese Scientific thought, seem in the works of naturalists at the service of the Portuguese Crown. 
These works can also be considered the first attempts at producing scientific thought about Brazil. The descriptions, drawings (and the main scientific action of naming plants and animals) created the corpus of knowledge upon which later descriptors searched for information, and were produced during a loosely defined Portuguese Enlightenment.

Sebastião José de Carvalho e Mello, Marquis of Pombal, had, during his time as strongman of the Portuguese monarchy (1750-1777), a number of stately objectives, the most cherished of which was to overcome the backwardness of Portuguese Science, as compared to other European Powers of the 18th Century. Being a man of the Enlightenment, ${ }^{1}$ Carvalho e Mello believed in the power of education, and his actions - one might say, his "projects" - were frequently related to complete educational reforms. The first step in this general direction was the creation of the Colégio dos Nobres, which intended to give scientific qualification to the Portuguese nobility and future leaders of the Empire. For this task, Italian professors were brought into Portugal, amongst whom was Domingos Vandelli, who eventually became the leading individual responsible for the development on the natural sciences in Portugal.

Instead of teaching at Colégio dos Nobres, as he was originally meant to do, Vandelli devoted himself to bringing to effect two other of Pombal's projects, On the one hand he contributed directly to the reform of the Coimbra University, with the introduction of the Philosophy courses, which, in 18th Century terminology meant the Natural Sciences, and the Mathematics course, which included astronomy. ${ }^{2}$ On the other hand, Vandelli was responsible for the natural history complex set up near the unfinished building of Palácio da Ajuda, in Lisbon. The complex, made up by the Botanical Gardens of Ajuda, the Museum, the Chemical Laboratory and the Casa de Risco [drawing office], became an important center for the production of natural history knowledge, teaching and research in 18th Century Portugal. The animal compounds of the Real Quinta de Belém, where the living animals collected in the colonies were sent to, can be added to this complex.

Martinho de Mello e Castro, minister of the Office of Navy and Overseas, under whose authority were the natural history establishments, was also at the Ajuda palace. Although Vandelli continued - nominally - as director of the Botanical Gardens and its annexes, he ended up as the professor of natural sciences at the reformed Coimbra University, and he created botanical gardens in that city as well, in order to support the Natural Philosophy and Medicine courses. In practical terms, the Ajuda gardens were in the hands of Julio Matiazzi, a botanical gardener brought by Vandelli from Padova, under the orders of Mello e Castro himself. In order to increase the collections at the gardens, the minister took advantage of the colonial administrative network under his command, demanding that its members (employees of the Portuguese Crown) gather natural history items and scientific curiosities to be shipped to Portugal. ${ }^{3}$ This can be seen in the abundant letter exchange between Lisbon and colonial leaders in the Atlantic Islands, America, Africa and Asia.

Among those called upon to contribute to such collections were the governors of the Northeastern captaincies of Portuguese America, under whose jurisdiction the vast arid hinterlands (sertão) were included. Called Caatinga (both the geographical region and the vegetation), it is a dry shrubland of thorn forest like Cacti, thick stemmed plants, thorny brush

\footnotetext{
${ }^{1}$ Kenneth Maxwell. Pombal: paradox of the Enlightenment. New York: Cambridge University Press, 1995.

${ }^{2}$ Magnus Roberto de Melo Pereira, and Ana Lúcia Barbalho Cruz, Ciência e memória: aspectos da reforma da universidade de Coimbra de 1772. Revista de História Regional 14(1):7-48, Verão, 2009.

${ }^{3}$ Angela Domingues. Para um melhor conhecimento dos domínios coloniais: a constituição de redes de informação no Império Português em finais do Setecentos. Histórias, Ciências Sociais - Manguinhos 8:823-838, 2004; Lorelai Kury,. Homens de ciência no Brasil: impérios coloniais e circulação de informações (1780-1810). História, Ciências Sociais Manguinhos 11:109-129, 2001; Lorelay Kury. Histoire naturelle et voyages scientifiques (1780-1830) (Paris: L'Harmattan, 2001).
} 
and grasses. Located between $3^{\circ} \mathrm{S} 45^{\circ} \mathrm{W}$ and $17^{\circ} \mathrm{S} 35^{\circ} \mathrm{W}$, it extends across eight states of Northeastern Brazil, separated of the coast by a small fringe of Atlantic Forest and includes some areas of high plateaus, according to the definition by the Brazilian Agricultural Research Company (EMBRAPA). ${ }^{4}$

The first requests of specimens were made to such officers in the 1760 's, before Vandelli was called to Lisbon, when the Botanical Gardens were only a sketched project and the overseas Ministry was under Pombal's brother, Francisco Xavier de Mendonça Furtado. It was, however, under Mello e Castro in the 1770's, that the deliveries of zoological, botanical and mineral specimens became systematic. At first, the demands for specimen shipments concentrated on samples of the animal kingdom, in particular birds meant for the Royal States (Quintas Reais), to where many Caatinga specimens were sent. Orders to "send all kinds of quadrupeds which can be found" were issued to the Governors of Pará, Maranhão, Pernambuco, Bahia, Cape Verde, São Tomé, Angola and the Viceroy of Brazil, with the observation not to send any more "agoutis, monkeys, macaws and parrots", except if they presented "some uncommon rarity". 5

A partnership between the Minister and Manoel da Cunha Meneses, Governor of Pernambuco from 1774 to 1779 , made that Captaincy into a shipment center of tropical birds to Portugal, often accompanied by other animals and curiosities. Dozens of shipments of bird cages - at times with over one hundred birds each - were sent. His successor, José César de Menezes, continued the Process in the following years. Bahia also was the origin of more than seventy shipments of birds and other animals. Furthermore, as Recife and Salvador were stops on the African route, several other shipments arrived there from Angola, Benguela and São Tomé, at times including larger animals such as elephants and lions, which waited in those harbors until ships to Portugal were available.

As a result of this policy, animals from various Brazilian Northeastern ecosystems were dispatched to Portugal - many coming from the Caatinga. Besides the hundreds of small birds and parakeets, the shipments included vultures, rheas, nightjars, curassows, guans, tinamous and macaws. The mammals included deer, wild dogs, several cats (including jaguars), marmosets and a variety of small rodents. Lizards and snakes were often included as well. Although we can safely assume that most of these animals were meant to be used and were used - for scientific purposes, we must bear in mind that, like their European counterparts, the Portuguese Royal Family devoted itself to collecting zoological specimens, so it is safe to assume that such collections were completed by the shipments under scrutiny in this work.

With the objective of improving the natural products shipped to Portugal, the Lisbon Science Academy (Academia de Sciências) had a small manual published, in 1781, about how to prepare and ship animal, vegetable and mineral scientific samples. ${ }^{6}$ The manual also dealt with anthropological objects and how they should be gathered and shipped, in special indigenous artifacts, and insisted on the preparation of reports and memoranda describing the various places studied by the correspondents. This manual was distributed to governors and other high level employees throughout the Empire. In Bahia, for example, the governor wrote informing that he received the manual in May, 11th, $1782 .{ }^{7}$ If the manual fulfilled the expectations of those who conceived it, is a study yet to be carried out.

\footnotetext{
${ }^{4}$ See: http://www.uep.cnps.embrapa.br/zoneamentos_zane.php. Consulted in January, 19th, 2015.

${ }^{5}$ Arquivo Histórico Ultramarino (AHU), Códice 65, f. 69.

${ }^{6}$ Breves instrucções aso correspondentes da Academia das Sciencias de Lisboa sobre as remessas dos produtos e noticias pertencentes a historia da natureza para formar um Museo Nacional. 1791 Lisboa; Tipografia da Academia.

7 AHU, Bahia, Castro e Almeida, D11.008.
} 
In 1778, Martinho de Mello e Castro and Domingos Vandelli began to prepare a large scientific expedition to Brazil: the Philosophical Journey. A number of recently graduated students from Coimbra were chosen for the enterprise. The team - composed entirely of Brazilian subjects of the Portuguese Crown - included Alexandre Rodrigues Ferreira, named chief of the expedition, João da Silva Feijó, Joaquim José da Silva e Manuel Galvão da Silva, as well as the artists and gardeners which would accompany them. After being chosen, they were gathered in the Ajuda Complex in order to complement their education before going into an exploration journey.

However, towards the end of 1782 there was a change of plans and the team meant to be sent to Brazil was broken up in smaller teams to be distributed to several regions of the Portuguese Colonial Empire. Throughout 1783, these smaller groups were sent to the colonies: Ferreira left for the Amazon, with two artists and one gardener. The Silvas, each heading a small team, were sent to Angola and Mozambique, both as naturalists and secretaries of State. Feijó was assigned of exploring, by himself, the Cape Verde Islands.

News of the expeditions and the stimulus from the Crown had already reached the upper echelons of the colonial administration. Even before the teams left Portugal, some governors sponsored "philosophical" journeys in their captaincies. In Sao Paulo, around 1778-1779, Governor Martim Lobo de Saldanha ordered Fray Mariano da Conceição Veloso to "collect the country's most precious products to be sent to His Majesty's Museum and Garden". ${ }^{8}$ In 1789, The Viceroy of Brazil requested Veloso to do the same in the Rio de Janeiro Captaincy, resulting in Veloso's Flora Fluminensis, a landmark in the development of Linnean Botany in the Portuguese Empire.

The starting point of the scientific exploration of the Caatinga was also a result of such anticipations. In 1784, José Teles da Silva was appointed Governor of Maranhão and, as part of his staff when he traveled to São Luis to take office, was João Machado Gaio, a native of Pernambuco who had studied in Coimbra and had been pupil of Vandelli - as had Teles da Silva. As soon as he arrived in Maranhão, Teles da Silva ordered Gaio to make a philosophic journey to the Ibiapaba Montain range. ${ }^{9}$ Although in the past, the plateaus were not usually included in the Caatinga, it is widely accepted today that they are one of the major landscapes of this biome. ${ }^{10}$ Therefore, it is conceivable to consider Gaio's expedition into Ibiapaba as the first enlightened scientific voyage into the Caatinga.

The choice for exploring Ibiapaba was not a random one, considering that the higher, cooler regions of the Brazilian Northeast were regarded, since the 17th Century, as potential colonies for European settlers. They were noticeable mainly due to the strong contrast with the arid coastlines of Maranhão and Ceará. The Ibiapaba range was already home to the best established indigenous settlement of the region, Vila Viçosa Real, whose inhabitants Gaio surveyed, and more than one governor of the captaincy manifested his desire to bring in settlers from the islands of Madeira and Azores to the region.

Machado Gaio traveled through the Serra da Ibiapaba from July 13 to August 6, 1784, and wrote a short "memory" 11 of his philosophical journey, which strongly reminisced the

\footnotetext{
${ }^{8}$ AHU, Reino, Maço 2719 .

${ }^{9}$ João Machado Gaio. Viagem filosófica que por ordem e despeza do Ilmo Exmo Snr Joze Tellez da Silva Governador e Capitam General do Maranham fez Joan Maxado Gajo na Serra da Ibiapaba Capitania do Seará Grande Termo de Vila Viçosa Real, desde 13 de Julho de 1794 até 6 de agosto do dito anno. AHU, Maranhão, cx. 64, D5719.

${ }^{10}$ José Maria Cardoso Silva et. al. Biodiversidade da Caatinga: áreas e ações prioritárias para a conservação. Brasília: Ministério do Meio Ambiente, 2003.

${ }^{11}$ The papers produced by members of the Academia de Sciencias were often named "Memórias", which translates badly into Memories, but is not what the English gallicism Memoir means. Although lacking in definition, we opted to use Memory or Memories when referring to such written reports.
} 
term papers Vandelli demanded of his students after they were sent for a short journey to the mountains near Coimbra.

I have observed that this mountain is to the most part covered in vegetation; some [which were] minimally known, spared me the trouble of collecting them for the herbarium: others, however being unknown to me, I have taken care in reducing using Linné's method. Among them I found a plant, which after much work I could not determine the genus; but I have collected it and made a rigorous description, naming it Tellezium, in honor of His Excellency José Telles da Silva my Governor and Captain General, who has sent me on this journey giving me all I have needed, and sage instructions which he learned better than myself from our master, the very Sapient Dr. Vandelli, at Coimbra University.

I have observed abundant [trees] of Urucum whose scarlet color is [bound] to be appreciated as much as that of the cochineal. I have observed [Tossuna?], whose yellow is so vivid and fine it must be preferable to the one produced by chemists in their industrious processes and resolutions. I have observed [Sonunga?] whose leaves, after fermentation, leave an immensity of blue particles at the bottom of the pot. For lack of convenient [means] for the operations I didn't go beyond the theoretical, constrained and malcontent. I carefully noted the copious number of palm trees, from the pericarp of which the Americans extract oil, with which they do some barter business, necessary to the satisfaction of primary needs. I have observed timber, which can be used for ship building, and others, that can have different uses after modified by the artisan. Among these [latter woods] one caught my eye for being denser, and of better color and duration, o Gonzalo Alz', which, with others, I did not reduce due to the fact that they had already bore fruits, being [therefore] irreducible.

Numerous plants are used as medicine by the Americans, but this knowledge is kept obstinate silent by them, since they attribute a great deal of their happiness to it.

In fact, Gaio didn't measure up to the task, and he wrote a rather rudimentary memory of the journey. Upon returning to Maranhão, he made the first shipment of specimens from the Caatinga with scientific intent. In the first crate, Machado Gaio sent several mineral samples: plumbago (graphite), schist, ochre, mica, silver and copper ores. In another crate, other types of minerals were sent: colored quartzes, flint, alum, lead, as well as a fossilized crab (Entomolithus cancri), and some samples of saltpeter. The last crate sent to Lisbon had, besides some Jatoba (Hymenaaea) resin and a swordfish head, a few plant specimens:

\begin{tabular}{|c|c|c|}
\hline \multicolumn{2}{|l|}{ Lignumvulgó } & Tossuna \\
\hline Lignumvulgó & f & Gonzalo Alz' \\
\hline Tellesium & & \\
\hline Sollanum & vulgó & Montanum \\
\hline Ixora & vulgó & Americana \\
\hline Justitia & vulgó & - Infundibili-formis \\
\hline Scabiosa & vulgó & Suecia \\
\hline Cotula & vulgó & Anthemoides \\
\hline $\begin{array}{l}\text { Doronicum } \\
\text { Tradescancia }\end{array}$ & vulgó & Pardilanehy \\
\hline $\begin{array}{l}\text { Monoginia } \\
\text { Ejewleva }\end{array}$ & vulgó & Diapencia \\
\hline Cryptogamia & vulgó ord & Filices \\
\hline
\end{tabular}


As Machado Gaio rarely mentioned the vulgar names of plants, we cannot know what he really sent to Portugal, since his attempts to "[reduce] using Linné's method" were often unsuccessful. He imagined that the solanacea he found was a Solanum montanum, an Andean species for which he mistook the many Jurubeba of the Caatinga. The Doronicum pardalianches is native to the Alps (the greater false leopard's bane) for which he confused some other local Asteraceae. ${ }^{12}$ Also, the Diapencia belong to a family whose occurrence is restricted to colder climates, especially sub-artic or the Himalayas, making it very unlikely to have been found in Northeastern Brazil. It is possible that he also sent seed or seedlings of Firecracker Flower (Justicia (crossandra) infudibuliformis), some varieties of Spiderworts (Tradescantia), which more or less sum up the whole shipment, as he focused upon garden flowers and leafy plants, not always native to the Caatinga.

The tree that most attracted his attention was the gonçalo-alves (Astronium fraxinifolium), whose timber is still in common use today. For over a hundred years it was harvested for railroad sleepers and was one of the native species of Brazil sent to the International Space Station for experiments with zero gravity germination. As for "Tossuna" and "Sonunga", no trees or bushes are actually known by those names, making it difficult to infer what he had actually seen. In a typical exercise of bajulatio, and pretending to be botanically knowledgeable, Gaio named what he believed to be an undescribed species after the Governor José Teles da Silva (Tellezium) - a common behaviour among naturalists all over Europe. Pitifully enough there are no clues today to what plant Tellezium would be.

Machado Gaio finishes his scientific exercise by forwarding his report on the "Philosophical Journey" to the Royal Academy of Sciences in Lisbon, with its publication on the Memorias da Academia in mind. Such distinction was not achieved, for obvious reasons.

During the following years, the Portuguese Crown and its officers did not sponsor any other official explorations of the Caatinga, and the official actions reverted to a previous pattern, restricted to the shipping of animals, mainly birds, and a few plants, seeds and curiosities to the Ajuda garden of the Royal States. There were, however, some private initiatives which attempted to systematically describe the region's fauna and flora. Albeit private, such descriptions were also the result of public policies, which stimulated the shipment of specimens and the writing of scientific texts. These became tools for demanding privileges and favors to the Crown. The political culture of the period pulled together scientific practices and the distribution of Royal privileges (mercês), characteristic of the Ancien Regime. $^{13}$

As for the Brazilian Northeast, this kind of experiment was more usual on coastal and forested areas in which there was a larger concentration of enlightened civil servants when compared to the Caatinga. However, since both regions share a large part of the fauna and flora diversity, Caatinga was included in such descriptions (albeit indirectly). The village of Cachoeira, in Bahia, was the main port of entry for scientific exploration of the hinterland, particularlly because two men of science lived there at the end of the 18th Century Francisco Antônio de Sampaio - a surgeon of Portuguese origin - and Joaquim de Amorim e Castro - a lawyer, (and judge after 1786) and naturalist born in Bahia.

Sampaio wrote an illustrated book on natural history, in which he described various specimens of regional fauna and flora, indicating some as belonging to the Caatinga. ${ }^{14} \mathrm{He}$

\footnotetext{
${ }^{12}$ Also called Compositae, refers to the family of daisies and sunflowers.

${ }^{13}$ See Ronald Raminelli. Viagens ultramarinas; monarcas, vassalos e governo à distância. São Paulo: Alameda, 2008.

${ }^{14}$ Francisco Antonio Sampaio. "História dos reinos vegetal, animal e mineral do Brasil pertencente à medicina". Anais da Biblioteca Nacional, v. 89, (1969).
} 
wrote, for example, about a species of wild pumpkin that "normally grows in the low bush areas that are called Caatingas". ${ }^{15}$ Although he did not try to define, or describe, what was understood by Caatinga, his text is marked by the binary opposition of a forested highland and a lower, bush terrain.

In the volume devoted to the fauna, in several parts, Sampaio's text becomes a direct dialogue with Linée, complementing or diverging with the latter. Differently from the Swedish naturalist, Sampaio places himself as an observer, who handles the specimens at the very moment the description is being made, stating insistently: "I see". He described some of the species to be found in the Caatinga, especially the Dasypus, and he refers to two varieties of armadillo: one, smaller, probably being the one described by Carl Von Linné (Cabassous unicinctus - or the Southern naked-tailed armadillo) and a larger one, which he names true armadillo, up to that date not included in any zoological compilations. His perception was confirmed in 1804 by the zoologist Gaetan Desmarest, who described the Cabassous tatouay. ${ }^{16}$ Another member of the Dasypus family that Sampaio claimed to live "in the forests, Caatingas and fields in caverns which it digs in the earth" is the six-banded armadillo (Euphractus sexcinctus). ${ }^{17}$ Through his description, Sampaio became one of the authors responsible for bringing into the scientific thought of the 18th Century, the popular belief that these animals dug up graves to eat corpses.

Sampaio also dedicated himself to studying South American pigs, describing both the caitetu (Tayassu tajacu) and the queixada (Tayassu pecari). As for the rodents of the Caatinga, he painted a rather similar portrait to that of today. There are porcupines (Coendou prehensilis), as well as squirrels (Sciurus aestuans) and several members of the cavy family like the Agouti (Dasyprocta primnolopha) and Spix's yellow-toothed Cavy (Galea spixii). The Rock Cavy (Kerodon rupestris), not present in Linée's works and described only in the 1820's by Prince Malimilian Wield-Neuwied, was defined by Sampaio as being similar to the (later named) Spix's Cavy being only "a bit larger, with a reddish color", as well as giving details of its habitat: "Always lives in holes in large rocks, coming out at dawn and nightfall in search of sustenance. I have seen them in large numbers sitting in rocks, sitting timidly and fleeing at great speeds at the slightest sound and hiding, and you can only kill them with rifle shots." ${ }^{8}$

Joaquim de Amorim Castro also devoted himself to studying the fauna and flora in the region. As it was the case with Manuel Arruda da Camara, his motivations were utilitarian. He studied the production of cochineal and tobacco - which was one of the main export products of the region. With Vandelli, Câmara and many others, Castro contributed to the effort in finding an economically viable replacement for the fibers used in making ropes, since such fibers were not grown in the Portuguese Empire. He published in Memórias Econômicas da Real Academia a small treatise on the hibiscus fibers (Malvaviscusman arboreus) and another about the cochineal. ${ }^{19}$ Having named his collected manuscripts as História Natural do Brasil segundo o sistema de Lineu ${ }^{20}$ (Natural History of Brazil according to the system of Linée) with his more utilitarian texts and the descriptions of some animals and plants of the region, he also wrote an illustrated codex in which he described and presented

\footnotetext{
${ }^{15}$ Francisco Antonio Sampaio, tomo I, p. 71; estampa 19, figura 7.

${ }^{16}$ Idem, tomo I, p. 54; estampa 12, figura 3.

${ }^{17}$ Idem, tomo 2, p. 10 e 12; estampa 3, figura 3 e estampa 4, figura2.

${ }^{18}$ Francisco Antonio Sampaio, tomo 2, p11. Estambpa 4, figura 3.

19 Joaquim de Amorim e Castro. Sobre o Malvaísco do destricto da Vila da Cachoeira no Brasil. Memorias economicas da Academia Real das Sciencias de Lisboa 2: 135-143.

${ }^{20}$ Joaquim de Amorim e Castro. Historia natural do Brasil segundo o sistema de Lineu, com descrições de alguns animais e observações sobre a cochonilha, tabaco, salsa, e à nova prensa cilíndrica para a fatura de tabaco de folha com estampas exatas e fieis. Fundação Biblioteca Nacional [FBN], 11, 2, 022.
} 
drawings of 46 species of timber trees, spread over the Caatinga, such as the genipa (Genipa americana) and the mastic tree (Myracrodruon urundeuva). ${ }^{21 .}$

After these two "enlightened" and mostly private efforts, the Caatinga only returned to the official Portuguese scientific agenda at the end of the 18th Century, due to strategic and mineralogical matters rather than to any pure scientific interest. In 1796, when D. Rodrigo de Souza Coutinho succeeded Martinho de Mello e Castro in the Ministry of the Navy and Overseas upon the demise of the latter, Souza Coutinho (a godson of Pombal) continued several of the projects started up by the Marquis, giving them his own touch. Due to the intense warlike European scenario after the first few years of the French Revolution, his immediate concern was to diminish Portugal's dependence on saltpeter imports - the main raw material for the production of gunpowder. Self-sufficiency in the production of good quality gunpowder was considered essential to Portuguese sovereignty in Europe and the preservation of overseas territories, since the independence of the British colonies in North America was a clear sign of danger for Portugal. To accomplish such goals, Dom Rodrigo developed a policy of co opting the Brazilian colonial elite, bringing their sons, graduating from Coimbra University (even those suspected and convicted of participating in the 1789 independence Conspiracy in Minas Gerais), into his orbit of public services, quite often as naturalists.

In the same year he took office as the Minister of Navy and Overseas, D. Rodrigo wrote to the Viceroy of Brazil, and various governors of the captaincies, ordering investigations into the existence of economically productive saltpeter deposits. Such orders resulted in a number of practical actions in the field, notably in São Paulo, Pernambuco, Bahia and Minas Gerais.

In Lisbon; Don Rodrigo gathered a team of Brazilian born subjects of the Portuguese crown with scientific training to help him in this enterprise. Fray Mariano da Conceição Veloso, who had gone to Portugal to try to publish his Flora.Fluminensis, was recruited as the editorial right hand of the minister, but not only that; Veloso was instructed to translate and publish several books on the production of saltpeter - which would be the starting point for the Arco do Cego publishing house in 1799. ${ }^{22}$ These books were generously distributed in the Colonies, while Veloso and the naturalist João da Silva Feijó were given the task of experimenting with the chemical and Manoel Jacinto Nogueira da Gama, a personal friend to Don Rodrigo, was responsible to boost saltpeter production at the Braço de Prata saltpeter factory in Lisbon. In Brazil, attempts to find new natural saltpeter deposits or produce it artificially, involved, in São Paulo, the naturalists João Manso Pereira and Francisco Vieira Goulart, and in Minas Gerais, Joaquim Veloso de Miranda and Antonio Vieira Couto.

Concerning the study of the scientific exploration of the Caatinga, the process started when Souza Coutinho ordered the physician and naturalist Manuel Arruda da Câmara to organize an exploration voyage through the Northeastern hinterland. Câmara crisscrossed the Caatinga between 1797 and 1799, from Pernambuco to Ceará. ${ }^{23}$ The instructions given to Câmara insisted he should investigate mainly the saltpeter veins, but he did more, devoting himself to the study of several natural products of economic interest. In 1801 he received a new assignment by the Crown, to study fiber producing native plants, which in turn led him to describe several vegetation species of the region, particularly land bromeliad, such as the

\footnotetext{
${ }^{21}$ Joaquim de Amorim e Castro. Relação das madeiras que se encontram nas matas do termo da vila da Cachoeira. AHU, Bahia, Castro e Almeida, D13768-137815.

${ }^{22}$ See Magnus Roberto de Mello Pereira. D. Rodrigo e frei Mariano: A política portuguesa de produção de salitre na virada do século XVIII para o XIX. Topoi 15, 29, 2014.

${ }^{23}$ About the voyages of Câmara to the Northeastern hinterlands, see: José Antonio Gonsalves de Mello. Estudo Biográfico. In: Manuel Arruda da Câmarara. Obras reunidas (Recife: Fundação Cultural Cidade do Recife, 1982), 25-35.
} 
caroá, gravatá, coroatá, ananás manso (of the pineaple family) and the pita (agaves) ${ }^{24} \mathrm{He}$ also described the uses and extraction of carnauba wax (Copernicia prunifera), and other species in his lost manuscripts of Centuria Plantarum Pernambucensium. His study on cotton growing, published in 1799, was perhaps the first printing of a scientific text attempting to define the Caatinga:

Caatinga, in the strictest meaning of the term, means a land full of or covered by a species of cassia shrubs, not yet described by Linné, to which I have given the name moscata, but Lato modo, Caatinga is also land covered with any other low bush, such as the quince, velame (flannel flower), Broterea velame, and the name has become so generalized that today in some parts the name Caatinga is given to everything that is not river lowlands, even if it covered in virgin forest. The Caatinga is second only to the lowlands for cotton growth, although the quince Caatinga and the others are to be used only if there is no other kind of land available, since the cotton trees planted there do not usually produce for over three years, and even so, do not pay the efforts of the farmer. ${ }^{25}$

While Câmara explored the space between Pernambuco and Ceará, Don Fernando José de Portugal, by orders of Don Rodrigo, ordered José de Sá Bittencourt Acioly to try to restart the saltpeter production in the Montes Altos mountain range. Some decades earlier, a long experiment of producing the compound took place, ending due to a number of different conflicts. Acioli, from Minas Gerais and under suspicion of being part of the 1789 sedition movement, lived in an unofficial exile in Ilheus, and took the mission as an opportunity to redeem himself in the eyes of the Crown. So, he tried to establish inhabitants in the region, in order to restart saltpeter production, and reopen the road to the coast to be able to transport the production. He wrote two memories of his experiences, describing, once again, the highlands, marginal to the Caatinga ${ }^{26}$ Even though his attention was focused into saltpeter production, Acioli proved to be a good observer of the natural landscapes he visited:

\begin{abstract}
The base of this mountain range [Montes Altos] is covered in medium high forest which the natives call thick Caatinga, the rest of the land being low and flat, covered with low bush, which they call tame Caatinga, which can provide firewood for many centuries to come. [...] it forms a semicircle [...] to where all the rivers run that have their springs on the top of the mountains which are covered with grassy fields, and hay, with groves of trees spread around, called Agreste, and in parts covered with thick Carrasco, which is called Catanduvas [..]
\end{abstract}

Observing the landscape at Montes Altos, Aciolli went beyond simple description writing his texts in such a way that local knowledge, expressed in the formula "which they call", transits to enlightened scientific knowledge. Local designations, such as Caatinga and Agreste pass from Ethno-geography to Geography; from Ethno-botany to Botany, transforming local current knowledge-into abstract data, fixed and disconnected form the culture that produced it. ${ }^{27}$

\footnotetext{
${ }^{24}$ Manuel Arruda da Câmara. Dissertação sobre as plantas do Brasil que podem dar linhos (Rio de Janeiro: Impressão Regia, 1810).

${ }^{25}$ Manuel Arruda da Câmara. Memória sobre a cultura dos algodoeiros. Lisboa: Casa Literária do Arco do Cego, 1799.

${ }^{26}$ José de Sá Bittencourt Acioli. Sobre os meios de realizar a extração do salitre dos Montes Altos. 1799. sobre a viagem do terreno nitrozo. AHU, Bahia, CX, 213, Di 5016.

${ }_{27}$ See Bruno Latour. Centers of calculation. In Science in action. (Harvard, Harvard University Press, 1987), 215-257.
} 
Local knowledge, which then became scientific, sometimes employed words of Portuguese origin, modified by American usage, and sometimes, words appropriated from the Tupi language. Agreste is such a case of an "Americanized" Portuguese word. The adjective agreste, a depreciative, was used, according to Bluteau's dictionary of 1712 , to define anything rustic, unruly or uncultivated. ${ }^{28}$ In contrast to the coastal forest areas where the indians lived and the recently arrived Europeans had developed colonial agriculture, the Agreste, transformed into a noun by local Portuguese-Brazilian knowledge, was the landscape of less exuberant vegetation which appeared as one went further inland. In some places, the Agreste was even more arid than the Caatinga, and defined by an indigenous word with Portuguese appropriation: Catanduvas (caá=bush + tã =rough + dyba instead of tyba $=$ abundant) ${ }^{29}$

After the in loco observations made by Arruda da Câmara, D. Rodrigo decided to continue the scientific exploration of Cearás hinterlands, having in mind, mainly, saltpeter production. He sent, therefore, to the Captaincy of Ceará the naturalist João da Silva Feijó, a former partner of Fray Veloso in the initial experiments made in Lisbon. Feijó began, in 1799, attempts to produce saltpeter in Tatajuba, in the Cocos mountains, where Arruda da Câmara ended his expedition. ${ }^{30}$ Feijó's interests, however, went beyond saltpeter production. As soon as he arrived in Ceará, he wrote to D. Rodrigo about his intent to write a Flora Cearensis:

My personal inclination in Botanical studies has led me to examine some of this fertile country: it offers me a vast field for an interesting Flora, if your excellency would be pleased to suply me with some necessary books, such as the edition of Gmelin, the Botanic Encyclopedia of Fabricius, and the assistance of an illustrator. ${ }^{31}$

He wrote again the following year, asking the minister to send him the latest edition of Linné's Sistema Plantarum and Fusée Aublet's Flora Guianense. ${ }^{32} \mathrm{He}$ also asked for paper and a press for drying and pressing plants, which indicates he intended to set up a herbarium.

The saltpeter experience was aborted, due to high costs and the transfer of D. Rodrigo to the Royal Treasury, in 1801. Feijó was, then, free to devote himself to other activities, closer to his own personal preferences. He started to write about several subjects related to the economy of Ceará, and to systematically gather botanical specimens, sending them to the Royal Botanical garden. He was also instructed, from 1803 to 1806, to do so for the Prussian crown, which asked the Portuguese king for such specimens. This can also be seen in his project to write a Flora Cearensis, through which he intended to go beyond the task of a mere collector, and became a true naturalist, who, according to Linné, "understand Botany through its fundamentals". ${ }^{33}$

Feijó ended his carrier in Rio de Janeiro, teaching Zoology and Botanics in the Military Academy. He seems never to have completed his Flora Cearensis, which he named Coleção

\footnotetext{
${ }^{28}$ Rafael Bluteau. Vocabulario portuguez e latino aulico, anatomico, architetonico, bellico, botanico. Coimbra: Collegio das Artes da Companhia de Jesus, 1712, v. I, p. 84.

${ }^{29}$ Orlando Bordoni. Dicionário: a língua tupi na geografia do Brasil (Campinas: Ed. do autor, 1898), 156.

${ }^{30}$ On Feijó's trajectory and life, see Magnus Roberto de Mello Pereira and Rosângela Santos. João da Silva Feijó: um homem de ciência no Antigo Regime Português (Curitiba: UFPR, 2012).

${ }^{31}$ AHU, Ceará, Cx. 14, D. 811.

${ }^{32}$ Fussé Aublet. Histoire des plantes de la Guiane Françoise (Paris: Didot, 1775).

${ }^{33}$ Caroli a Linné. Systema plantarvm apud Varrentrapp filivm et Wenner, 1780. [Carl von Linné. Fundamentos botânicos que expõem, em fórma de aforismas, a theoria da scieñcia botanica de Carl von Linné (Lisboa: Offc. De Joaquim Thomaz de Aquino Bulhões, 1809), 5.
} 
descritiva das plantas da Capitania do Ceará. According to the naturalist Freire Allemão, "the originals were sold, upon his death, among old papers to a bakery; except for some pages he had entrusted me to copy". ${ }^{34}$

Albeit incomplete, Feijó's Coleção descritiva was, for many decades, the longest compilation about the flora of the Caatinga. It follows Linée's species description standards, displaying the plants according to the several botanical classes of the time. If a species was already described in the works of Linnée, Jussieu or Tournefort, the classification and name given by these naturalists was adopted. The sexual and morphological characteristics were described in Portuguese and Latin. Then, the Portuguese, English and French common names were given, as well as the type of terrain and the vegetative period. Feijo adds notes on the alimentary; medicinal or officinal uses given to the plant, as in the case of the Cepus or Casuna:

\begin{abstract}
Casuna - means blue leaf, composed of two terms = câ-which signifies leaf, and asuna=which means "something blue". The indian women dye their cotton clothes with the leaves of this plant: its color is similar to ordinary indigo [...] extracted by the same process as indigo. They also use a solution of ash and water to fixate the color on the cloth, the same method used by the inhabitants of the Cape Verde islands. This plant would, without any doubt, be of great use it it weren't ours; it is easy to grow, which would be enough to replace the common indigo: it is much richer in starch, because it has a large leaf.
\end{abstract}

In spite of being the best known name to study the Northeastern hinterland flora, Feijó rarely used the word Caatinga. In general, he was not prone to describe the landscape. In his work, Caatinga is used once, when he writes about the definition of the limits of Ceará, saying that there was a "widespread low and thick forest named Catinga do Góes, which goes from the highlands of Saint Sebastian to the Monseró river". ${ }^{35}$

Another heir to Arruda da Camara's saltpeter searching mission in the Northeastern hinterland was the priest Joaquim José Pereira, who had found, in the early 1790's, clues to saltpeter in the lands around Valença, when he was called to Portugal. There, he spent time in the Braço de Prata, with Nogueira da Gama, and learned the processes of the artificially produced saltpeter. He went back to Northeastern Brazil with orders to search the captaincies of Maranhão and Piauí at the exact same time Feijó was searching Ceará. He was joined by Vicente Jorge Dias Cabral, also commissioned by the crown. Both traveled the hinterland from 1799 to 1803 , in order to make a vast assessment of the local nature and its economic potential. They had, however, direct orders to seek "natural or mineral saltpeter, the main objective" of their observations. Therefore, they devoted a group of memories to the subject. Notwithstanding; they exceeded, in their writings, this particular focus. Pereira was born in the region, and was the first to study the Northeastern droughts as a specific object matter, during the 1792-3 drought. ${ }^{36}$ Although kept busy by the saltpeter search (as well as other chemical products) he directed his gaze, several times, to the regional landscape. The contrast between the dry lands and green forests, in Piaui, called for the descriptions of the Caatinga:

\footnotetext{
${ }^{34}$ Fundação Biblioteca Nacional, 10, 1, 012.

35 João da Silva Feijó. Memória sobre a Capitania do Ceará. Revista trimestral do Instituto do Ceará. 3. 1889 , 3-27.

${ }^{36}$ J. M. P. Vasconcelos. Selecta Brasiliense (Rio de Janeiro. Laemmert, 1868), 264.
} 
Tired os seeing dry fields with not a single green tree growing, the Serra dos Matões was a wonderful sight for me. To see the hills covered in continuous green, crisscrossed by pristine fresh water streams, with excellent farming land, which reminded me of those in Minas Gerais, dense forest, large fruit trees, while the Serra Grande, which is not far away, is quite the opposite: dry fields, blackish still waters; rough, intransigent, dry and fruitless bush, called catinga in local vernacular. What a noteworthy diversity! ${ }^{37}$

At times, he resorted the same words used to describe the arid landscapes of Portugal, and the Caatingas became "the dry desert thorny moors with a multitude of low thick plants covering the planes and hills". ${ }^{38}$ Vicente Cabral, in turn, looked at the Caatinga with a bias that mixed native vegetation, local usage and economic potential: "Catinga is a dry, low, very rough and dense bush, which loses all its leaves in the Dry Season, or summer. It is destroyed through fire, to grow pastures for the cattle; In the Catingas, and between rocks is where the cochineal cactus grows." 39

As for studying the Flora, Pereira was quite modest. He only wrote a list of vegetation in the captaincies of Maranhão and Piauí, and described a native quinine tree, which he named Quina-quina piauiensis. ${ }^{40}$ Describing the hinterlands of Ingá, he made a short list of animals, made up of only."horses, cows, jaguars, tapirs, boars, crocodiles, etc. He also wrote a list of birds: "Mutum [Curassow]; Jacu bird; Jacamim [Trumpeter bird], Macaw, Araruna [Blue and Yellow Macaw], Canindé [Blue and Gold Macaw], Vulture, etc". ${ }^{41}$

Vicente Jorge Dias Cabral, on the other hand, showed a larger inclination towards Botany. As we have seen, the students at Coimbra University, after the reforms promoted by the Marquis of Pombal, had to study Natural Philosophy, which enabled them to botanical studies. Machado Gaio seems not to have profited from his education, while Dias Cabral put it to better use, risking several incursions in this field of knowledge. His philosophic voyage and botanical writings paved the way for his nomination as Language (Letras) Professor in Maranhão.

Cabral sent several shipments of regional plant specimens to Portugal, amongst them the Manaca (Browallia demissa), of which he wrote a specific description, focusing mainly in its medicinal use as a cure for syphilis:

This medicine, when applied to several people has produced marvelous effects curing them of old venereal pains, and deserves, therefore, serious attention. The indians take it to cure veneral disease. Similarly, the juice of the plant named $=$ Mururé $=$ is used for the same purpose, and of which they also tell great marvels. I hope still to work on its reduction, as soon as the branches, which the wise and very vigillant excellent lord General D. Diogo de Souza sent for, arrive.

\footnotetext{
${ }^{37}$ About the philosophic voyage of these two naturalists, see: Tiago Bonato. Da investigação mandada fazer por V. Exa. sobre os diferentes produtos da natureza: dois viajantes iluministas pelo sertão da América Portuguesa (Curitiba: UFPR, 2007).

38 Joaquim José Pereira. Memoria sobre a extrema fome e triste situação em que se achava o sertão da riberia do Apody da capitania do Rio Grande do Norte, da comarca da Paraíba de Pernambuco onde se descrevem os meios de ocorrer a estes males futuros. Revista do IHGB 20 (1857): 175-182.

${ }^{39}$ Vicente Jorge dias Cabral. Memória sobre as nitreiras naturaes da parte inferior da Capitania do Piauhÿ. AHU. Maranhão, cx 127. D9555.

${ }^{40}$ Joaquim José Pereira. Descripção da Quina Quina Piahuense. AHU. Maranhão, cx 127, D. 9555.

${ }^{41}$ Joaquim José Pereira. Observações deste diáriō ou Memória sobre as produções naturaes. 1799. AHU. Maranhão, cx 127, D. 9555.
} 
It seems that nature knows how to produce anti-venerial remedies in the same climate in which the disease had its origin. (a)

(a) Some celebrated writers are persuaded that the Americans communicated the French disease to the Europeans, whereas the latter gave the Americans smallpox.

Machado Gaio, mentioned above, did not hold a monopoly on botanical bajulatio. Vicente Cabral went beyond paying homage to a single governor. He tried to gather several species of rush-foil (Croton L.) into a new genus, which he named Ad'minister, in honor of some Portuguese ministers. He named the black rush-foil (velame preto) Ad'minister rodericus; a larger species was called Ad'minister souza; one with small leaves was named Ad'minister coutinica and, finally, a perfumed species was named Ad'minister odarolissimus. The description of these, and other species of plants is included in Cabral's major work: the Ensaio botanico de algumas plantas da parte inferior do Piauí. ${ }^{42}$

Although his Ensaio was much shorter than Feijo's Coleção descritiva, Cabral had the good fortune to have the help of an illustrator, which gave his flora a more finished aspect. Nevertheless, in the end, both works shared the same fate: they remained forgotten in Brazilian and Portuguese archives.

Also mostly unknown were the works of Amorim de Castro Sampaio, and Arruda da Camara's Centuria Plantarum simply disappeared. Therefore, the larger part of Portuguese 18th Century scientific knowledge about the Caatinga was unpublished, with the exception of a few memories of immediate utilitarian nature, which were then used by several authors to try and discredit the scientific production of Portuguese Enlightenment as "merely utilitarian".

However, as it can be observed on the studies of the Caatinga, almost everyone involved was occupied - mostly in vain - with "pure" (or not applied) scientific knowledge, such as the collection and description of botanical and zoological specimens.

Plants and animals sent to Portugal had similar fate to the texts. Had they been used as a complete set, these shipments could have had established the basis for scientific knowledge of the fauna and flora of the Caatinga, which did not happen.

The Portuguese Crown, despite being able to organize the shipments to Portugal to a reasonable extent, was never able to promote the adequate scientific use of the material received, either due to lack of funds or to the small number of individuals devoted to scientific investigations in the Country.

The shipments had begun to go to (scientific) waste, for they were kept in their crates for years, or were poorly packaged, and deteriorated. This happened with the shipments from the first philosophic voyages, around 1783, and continued to be so in the latter period started by D. Rodrigo. It wasn't a complete loss, though. The herbaria of the period were used by Felix de Avelar Brotero and other Portuguese Botanists to describe a few species. ${ }^{43}$ Part of the material was "borrowed" by the Jardin des Plantes in Paris, during the Napoleonic invasion of Portugal. Feijó shipped specimens directly to Berlin and was rewarded by the Germans in the name of a guava species of southern Brazil: Feijoa sellowiana.

As for the study of the scientific impact of the shipments from the Caatinga, made by Portuguese Brazilian naturalists, both in Portugal and the whole of Europe, is still to be made.

\footnotetext{
42 José E. Mendes Ferrão, et. al. Plantas do Brasil; Flora económica do Brasil no século XVIII. Plantas do Maranhão-Piauí. Lisboa: IICT, 2002.

${ }^{43}$ See, for example, Felix de Avelar Brotero, Araujiä sericifera. Transactions of the Linnean Society of London 12: 62-70, pl. 4-5. 1818.
} 
Since the Portuguese scientific universe of the time was unable to carry out the complete process of knowledge production, the void was filled later by names like Koster, Spix, Martius and Wied-Newwied, celebrated in Brazilian historiography as "the inventors of Brazil". ${ }^{44}$ Such panegyric approach shows that these "foreign" voyagers of the 19th Century were not thought of as readers of the textual gender they produced. In their narratives, they insist on the experience of "being there". But they have left clues to the fact that their gaze was directed also by the printed and manuscript texts written by the preceding generation of Portuguese Brazilian naturalists. ${ }^{45}$

\footnotetext{
${ }^{44}$ See: Magnus R, M. Pereira, and Ana Lúcia Rocha Barbalho Cruz. A história de uma ausência: os colonos cientistas na América Portuguesa na historiografia brasileira. In: João Fragoso, et. al. Eds. Nas rotas do império (Vitória/Lisboa. Edufes/IICT, 2006), 357-389.

${ }^{45}$ On this subject, see Daniela Casoni Moscato. Viajantes leitores: algumas considerações acerca da presença das obras dos naturalistas luso-brasileiros setecentistas nos relatos de viagens dos oitocentos. At http://www.snh2013.anpuh.org/resources/anais/27/1364243592_ARQUIVO_TextodeComunicacaoANPUH2013.pdf, Seen in Aug. 11th, 2015
} 